\title{
Transgovernmental Networks and Cooperation IN THE Global SOUTH*
}

\author{
Redes transgubernamentales y la cooperación Sur-Sur
}

\author{
ISABELLA ALCAÑIZ
}

Universidad de Maryland

\begin{abstract}
Why do bureaucrats from developing countries cooperate internationally? I argue that international inter-agency cooperation in the Global South results from the need of expert bureaucrats to invest in skill formation when governments do not. When states cut funding, expert bureaucrats cooperate with foreign peers to upgrade their skillsets because career advancement is contingent on up-to-date expertise. To test my theory, I use cross-national co-sponsorship data of projects in nuclear energy, science and technology (NEST) for 69 countries (1980-2008). Results show that bureaucrats cooperate internationally when government spending decreases and that cooperation is more likely to occur among bureaucrats with higher initial skill levels and similar levels of professional development (i.e. homophily). These findings carry implications for the study of global governance in the developing world.
\end{abstract}

Key words: transgovernmental cooperation, social network analysis, skills, state, expert bureaucrats

\begin{abstract}
RESUMEN
¿Que explica la cooperación internacional entre burócratas expertos de distintos países en vías de desarrollo? Este artículo explica la cooperación internacional entre agencias inter-gubernamentales a partir de la necesidad que tienen los burócratas expertos de actualizarse profesionalmente cuando el estado deja de invertir en recursos humanos. Este argumento es testeado utilizando datos de participación en proyectos internacionales en el área de Energía, Ciencia, y Tecnología Nuclear para 69 países en desarrollo entre los años 1980 y 2008. Análisis de redes muestran que las agencias especializadas en temas nucleares aumentan el nivel de cooperación internacional cuando disminuye el gasto público en su país y cuando sus socios internacionales tienen niveles de desarrollo similares (homofilia). La presente investigación contribuye al estudio de la gobernanza global.
\end{abstract}

Palabras clave: cooperación transgubernamental, análisis de redes, capacitación, Estado, burócratas expertos

\footnotetext{
The author would like to thank Maria Victoria Murillo, Matthew Carnes, Ernesto Calvo, Kathryn Hochstetler, Tulia G. Falleti, other members of the REPAL network, the editors of RCP and two anonymous reviewers for invaluable comments and suggestions.
} 


\section{INTRODUCTION}

Why do bureaucrats from developing countries cooperate internationally? There is a sharp contrast between the widespread theoretical expectation of the bureaucrat as a domestically bound actor and her increasing international behavior. The significant recent growth of transgovernmental networks formed by collaborating state experts (Raustiala 2002; Slaughter 2004; Bach and Newman 2014) challenges traditional views of bureaucratic behavior that expect state agents to zealously guard domestically appropriated funds and resources (Blais and Dion 1990; Huber and Shipan 2006; Niskanen 2007). Despite such theoretical expectations, international inter-agency cooperation is evident across diverse policy areas and in all regions of the world. ${ }^{1}$ The extant literature on transgovernmentalism has focused overwhelmingly on the link between state experts and international cooperation in the industrial North (Haas 1992; Raustiala 2002; Slaughter 2004; Adler 2008; Bach and Newman 2014). Yet skilled bureaucrats working with foreign peers on large, complex projects in order to address common policy problems is becoming less exceptional in the developing world (Kahler 2000; Almeida, et al. 2010; Elliott 2012; Soulé-Kohndou 2013; Nganje 2015; Alcañiz 2016). This article explains the international cooperative behavior of state experts and their agencies in the Global South, who increasingly collaborate with foreign peers on technical projects and programs.

For several decades now, state agencies from Africa, Asia and Latin America have collaborated on nuclear (non)proliferation, climate change, water security, agricultural sustainability and the fight against AIDS, to mention just a few jointly-tackled problems. ${ }^{2}$ Cooperation in these policy arenas is predominantly project-based, which means state experts must cross national borders in order to negotiate and implement common goals, assign tasks and agree on a feasible division of labor. While there are great benefits to cooperation, such as knowledge exchange and new technology, there are also costs. When they choose to participate, bureaucrats and their agencies must commit to share with foreigners scarce and costly resources such as personnel, funding and skills. ${ }^{3}$

International inter-agency or transgovernmental cooperation is defined as a set of relations formed by the cross-border "interactions among sub-units of different governments that are not controlled or closely guided by the policies of the cabinets or chief executives of those governments" (Keohane and Nye 1974: 43). Transgovernmentalism and inter-governmental cooperation differ in that the former involves autonomous bureaucrats and their agencies forging transnational ties and the latter is directed by the political principal. There is a rich literature that studies how the professional incentives and preferences of bureaucratic agents shape the policy process and may determine political outcomes (Carpenter 2001; Huber and Shipan 2002; Huber and Shipan 2006; Gailmard and Patty 2013).

2 See Nganje (2015). At present, international technical projects are being carried out by state agencies from the Global South with some assistance by the United Nations World Health Organization, the United Nations Environmental Programme and the World Intellectual Property Organization.

3 As one Argentine nuclear bureaucrat explains the costs of international technical cooperation: "We could participate if we had the means. You have to be responsible for your own expenses and you have to have available personnel to work full time on this [...] there is a very important opportunity in terms of technology but limited resources may prevent us from taking advantage of this" (Roberto Ornstein, Director of International Cooperation of the Argentine National Atomic Energy Commission, 28 July 2006. Interview by author in Buenos Aires, Argentina). 
This outward orientation of expert bureaucrats from developing countries, who have historically operated under conditions of deficit, presents researchers with a puzzle that has not been properly answered at present.

Drawing from the literatures on bureaucratic politics and the political economy of skills, I argue that international inter-agency cooperation in the developing world results from the need of expert bureaucrats to invest in skill formation and upgrading when governments do not. I expect countries' previous levels of specialization and expertise among public servants to condition cooperation. I define skills as the learned capacities and expertise that bureaucrats use to carry out day-to-day tasks and solve concrete policy problems (Ericsson 2006). In that sense, skills are often acquired through the learning-by-doing model that entails working on technical projects. Yet, similar to well-documented market failures in the allocation of skills in the private workforce (Becker 2009; Streeck 2012), the state as an employer also may fail to invest in human capital (Schäfer and Streeck 2013). I posit that when the state cuts critical funding, expert bureaucrats and their agencies take skill investment into their own hands, cooperating with peers to upgrade their skillsets in order to advance in their own careers and to ensure that they remain competitive on the job market, which requires maintaining up-to-date technical expertise (Campion and Shrum 2004; Teodoro 2011; Schrank 2013). In contrast to bureaucrats in industrial countries, who may have access to research grants, professional development initiatives, or alternative employment opportunities in the private sector, state experts in developing countries face much tighter domestic labor markets and have more restricted access to additional resources. ${ }^{4}$

I test these expectations in the policy area of nuclear energy, science and technology (NEST) using an original dataset containing details of participation in regional technical NEST projects by 69 countries of Latin America, Africa and Asia over a period of 30 years. ${ }^{5}$ Regardless of variations in institutional capacity and bureaucratic structures, all countries in the sample have at least one state institution with jurisdiction over NEST policy (e.g. in order to regulate and safeguard the nuclear technology used in radiology and medical imaging) ${ }^{6}$ Project participants are the bureaucrats and the state agency with primary jurisdiction over nuclear policy. The data has been collected from the department of Technical Cooperation of the International Atomic Energy Agency (IAEA), which assists countries with some of the coordination costs involved in cross-

4 This paper does not test whether the logic of cooperation posited applies to the skilled bureaucrats of the industrial North. However, I intuit that given greater state budgets for R\&D and larger professional bureaucracies, spending cuts may trigger the same need for cooperation among Northern bureaucrats but not the necessity to seek international aid, as they should have greater resources available domestically.

5 See International Atomic Energy Agency (2015). The paper is motivated by bureaucrats' incentives, drawn from face to face interviews with numerous nuclear experts, but the unit of analysis is the primary state agency in NEST that participates in cross-national projects. Table A1 shows all 69 participating countries of my study.

6 Here I focus on peaceful cooperation, but many NEST activities are imbued with security concerns, given the potential risk of radioactivity, mishandling of sensitive technologies and-the greatest fear of all-nuclear proliferation. 
national projects. The quantitative data is supplemented by extensive qualitative data collected through face-to-face interviews with key actors. I use this data to describe the networks of NEST state experts and their agencies across the Global South, assisted by a variety of visualization techniques from the toolbox of social network analysis.

The key finding of this article is that international inter-agency cooperation in NEST policy areas is best explained by variations in prior levels of skills across cohorts of expert bureaucrats in state institutions and countries. Highly skilled bureaucrats and those from comparatively affluent agencies engage in more cooperative behaviour and cooperate more effectively, as they tend to work with foreign peers at similar levels of development; by contrast, state experts with lower skill levels not only cooperate less, but are also less effective when the do, as they tend to partner with bureaucrats from countries that are similarly poorly-endowed and have fewer resources to share. This article contributes to the important study of transgovernmental cooperation and global governance in two ways: in addition to offering empirically testable causal mechanisms, which are absent from much of the literature, it also shines a light on the considerable global governance originating from inter-agency cooperation among countries of the Global South, including Brazil, South Africa and Mexico.

The article proceeds as follows. In the next section I discuss my theory and formulate the study's central hypotheses. After that, I describe the networks of NEST agencies that work together on cross-national projects in the developing world. Subsequently, I present the data, the models and a discussion of the results. The final section offers a few concluding remarks.

\section{A DEMAND DRIVEN THEORY OF INTERNATIONAL INTER- AGENCY COOPERATION}

The new, cross-nationally cooperative behavior of expert bureaucrats does not fit traditional definitions of public servants. According to the literature, bureaucrats are generally reluctant to share resources and have a documented tendency to be inward-oriented (Blais and Dion 1990; Hoffer 2013). They are expected to take full advantage of their autonomy from politicians (Huber and Shipan 2006). Their main goal is to maximize their budgets (Niskanen 2007), ${ }^{7}$ and the only tie that truly matters is the one they forge with their political principal (Gailmard 2002; Huber and Shipan 2002; Bendor and Meirowitz 2004; Huber and Shipan 2006; McCarty 2012; Gailmard and Patty 2013). As a result, we should expect bureaucrats to resist the allocation of agency-appropriated funds to activities outside of their exclusive organizational purview, especially 
in the developing world, where state research agencies tend to be chronically underfunded and understaffed to begin with (Schwartzman 1994; Solingen 1994; Campion and Shrum 2004; Sarkar 2012). Thus, transgovernmental cooperation is costly to expert bureaucrats, even if projects are partly funded by specialized international organizations, like the IAEA. Yet despite the costs, state experts have created partnerships across national and even regional borders time and again. Over time, these partnerships have forged international networks through which bureaucrats and politicians coordinate policy and agree on solutions to common problems (Raustiala 2002; Slaughter 2004; Bach and Newman 2010; Bach and Newman 2014).

Why do bureaucrats in developing countries, embedded in chronicallyunderfunded domestic institutions and accountable to local politicians, collaborate with foreign peers? On an individual level, state experts have career incentives to keep their skills current, and understand that spending cuts imposed by the government typically affect funding for training and research and development. ${ }^{8}$ Similar to Becker's (2009) expectation that workers in the private sector put up with the cost of training when their employer does not, I argue that bureaucrats in technology-based agencies who depend on their expertise to do their job will also take skill-investment into their own hands when the state does not (Carpenter 2001). ${ }^{9}$ One way to access new skills and help ensure the survival of research programs and institutional knowledge is to cooperate with foreign peers in cross-national technical projects. Through these projects, state experts not only pool resources and share research costs, but, critically, they also upgrade their existing skillsets at the same time. Most bureaucracies have certification processes by which outside training and acquired qualifications are recognized and count towards internal promotions and pay raises. ${ }^{10}$ Indeed, politicians in impoverished states often welcome these external sources of training as inexpensive solutions to the problem of outdated expertise:

During the 2001 crisis, due to the budgetary restrictions, the INAP allowed communities of practice ${ }^{11}$ as a training tool. Because we have had drainage of resources, we allowed the certification of any number of activities to be considered as contributions to the development of technical and professional competence. These [activities] could be courses within INAP, but if by your own initiative you did them outside you could

8 See "Brazil forced to cut back science funding" and "Brazil takes a knife to science funding again" accessed at http://www.rsc.org/chemistryworld/News/2012/March/brazil-science-technology-budget-cuts-third.asp.

9 Becker's (2009) expectation is that while employers are likely to invest in specific skills for their workforce, they avoid paying the cost of genera -i.e. more transferable-training because of poaching fears.

10 Recognition of externally-certified training, such as participation in international workshops or projects, is carried out by the National System of the Administrative Profession (SINAPA) in Argentina; the National Institute of Public Administration (INAP) in the Dominican Republic; and the South African Department of Public Service and Administration, to name a few.

11 The interviewee defined "communities of practice" as "somewhat informal and often virtual professional networks to advance knowledge and innovation." 
get them recognized by INAP. The system also accepts participation in working teams and international projects (interview with a senior official at INAP, January 2014).

International technical cooperation not only sharpens skills, but also increases the professional reputation of participants at home (Campion and Shrum 2004; Alcañiz 2010). Partnerships with peers are highly desirable to bureaucrats because they help expand the size of their professional networks, and make them more competitive on the job market (Heclo 1978; Carpenter 2001; Campion and Shrum 2004; Alcañiz 2010). In state agencies of the Global South, where funding for training and professional development tends to be extremely scarce and employment opportunities in the private sector are few, international cooperation can have a significant impact on a bureaucrat's career (Campion and Shrum 2004; Slaughter 2004; Herrera 2010). Especially in the information age, training and renewed proficiencies can affect wages and career promotions both inside and outside of the state (Brown, et al. 2001; Estevez-Abe, et al. 2001; Danziger and Andersen 2002; Thelen 2004; O'Connell and Jungblut 2008). Consequently, as I will argue, the search for alternative venues for professional development in the absence of state support helps to explain the emergence of collaborative international networks of expert bureaucrats.

From my theory of the expert bureaucrat, I derive three central hypotheses. The first posits that patterns of state spending can be used to predict trends in international cooperation among the agents of that state.

Hypothesis 1: When government spending declines, bureaucrats from the primary NEST state agency will increase international cooperation (i.e., participate more in cross-national projects).

A second hypothesis focuses on individual-level incentives for cooperation. Scholars who study the political economy of skills have found that "there is a substantial body of evidence indicating that in-career training is highly stratified, with the result that those with higher skills or educational attainment are more likely to participate in training" ( $\mathrm{O}^{\prime}$ Connell and Jungblut 2008: 111; see also Estévez-Abe, Iversen and Soskice 2001; Thelen 2007). Similarly, my theory of the expert bureaucrat shares the assumption that professionals with greater technical expertise - as determined by the degree of specialization of their agencies and a proxy for the size of the country's pool of scientists-will be more active in collaborative networks. This is based on the expectation that the more professional and specialized the employing institution, the stronger the incentive of the employee to keep her skills current, as technology-intensive institutions will put greater technical demands on their workforce. In fact, my theory assumes an initial level of expertise in order for an investment in skill upgrade to pay off.

Hypothesis 2: Bureaucrats that have higher pre-existing levels of skills will cooperate more in cross-national projects than bureaucrats with lower level of expertise. 
Third and finally, if skill upgrading is the primary causal mechanism behind international inter-agency cooperation in NEST, the empirical analyses should reveal a strong homophily effect. Homophily refers to the tendency of actors who share similar characteristics to work together, as expressed by the adage „,birds of a feather, flock together" (McPherson, et al. 2001). Past research reveals homophily to be present in many collaborative networks, similar to the one studied in this article (McPherson, et al. 2001; Maoz 2012; Kinne 2013; Videras 2013; Alemán and Calvo 2013). If bureaucrats' priority is to advance their skills, they will want to seek out partners who have superior training. Consequently, most bureaucrats and their agencies would prefer to collaborate with foreign peers in advanced programs. However, partner selection goes both ways and experts with superior skills will naturally prefer to work with colleagues from more advanced agencies (or, if they are at the top of their field, with their closest peer institution). As not everyone will be able to get their first preference, I expect a second tier preference-to collaborate with bureaucrats in agencies of equal skill-to result in the dominant strategy. Hence, if individual-level skillinvestment is the driving strategy behind international cooperation among public servants in the Global South, we should find empirical evidence of skill homophily within the transgovernmental networks of nuclear bureaucrats.

Hypothesis 3: Cooperation will be more likely among two state agencies at comparable levels of country development and skills.

\section{Alternative Explanations}

I also test for supply-side theories of international inter-agency cooperation. Students of transgovernmentalism and epistemic communities depict the rise of these networks as a result of globalization and the cost it puts on noncooperation (Keohane and Nye 1974; Haas 1992; Slaughter 2004; Bauer 2006; Adler 2008; Hicks, et al. 2008; Biermann and Siebenhüner 2009; Jordana, et al. 2011). Consequently, I examine the effect of countries' levels of exposure to international trade on inter-agency cooperation in NEST. Relatedly, I control for the role of international organizations as an alternative source of resources (namely, financial aid and technical skills), following diverse research on international development and aid (Pavnick 2000; Slaughter 2002; Vreeland 2003; Bauer 2006; Chwieroth 2007; Hicks, et al. 2008; Biermann and Siebenhüner 2009). Finally, I control for standard domestic drivers of transgovernmentalism, including regime type, size of the economy and population (Bach and Newman 2014). 


\section{INTERNATIONAL INTER-AGENCY COOPERATION IN NUCLEAR ENERGY, SCIENCE AND TECHNOLOGY}

How do collaborative networks of NEST bureaucrats and their agencies originate, and what type of projects do actors in these networks advance? Over the past four decades, three major nuclear networks have evolved across the Global South: the Regional Co-operative Agreement for Research, Development and Training Related to Nuclear Science and Technology for Asia and the Pacific (RCA); the Regional Cooperative Arrangement for the Promotion of Nuclear Science and Technology in Latin America and the Caribbean (ARCAL); and the African Regional Cooperative Agreement for Research, Development and Training Related to Nuclear Science and Technology (AFRA). Experts from national state agencies with primary jurisdiction over NEST policy from 69 countries participate in AFRA, ARCAL and RCA, partly sponsored by IAEA. ${ }^{12}$ These experts have been described as: „commissioners or directors, scientific or technical directors. They have their jobs and are in a high position in their country, but when they work in AFRA, whatever they do here, all their resulting costs are covered by the country itself" (interview with a Program Manager for AFRA. June 2007), Participating state institutions (e.g. nuclear energy agencies, science and technology agencies, public research universities and ministries) vary greatly in degree of specialization, availability of resources and level of skill across countries.

Table 1 offers a breakdown of projects by area of application and region. By disaggregating by project type, we can see bureaucrats' policy priorities to acquire skills. For example, African bureaucrats in NEST invest the majority of their cooperation efforts in two critical areas: the environment $(24 \%$ of total AFRA projects) and human health (21\% of total AFRA projects). African countries are high-profile stakeholders in the protection of the environment, thus it is not surprising that NEST bureaucrats in the region are such active participants in these types of projects. Human health projects with a focus mostly on radiology and nuclear medicine are popular across all of the Global South, as they are a source of inexpensive training for doctors and technicians from public hospitals.

12 IAEA contributions are modest. For example, between 1983 and 2004 IAEA only contributed 13 million US\$ to ARCAL (for all countries). The same amount was put up by ARCAL participants, mostly through in-kind contributions (ARCAL-IAEA data, compiled by the author). 
Table 1. Projects by Policy Area and Region

\begin{tabular}{lcccc}
\hline \multicolumn{1}{c}{ Type of Project } & AFRICA & ASIA & LA & Total \\
\hline Agriculture/Food & 19 & 21 & 16 & 56 \\
Energy & 17.27 & 12.65 & 11.19 & 13.37 \\
Environment & 2 & 17 & 3 & 22 \\
& 1.82 & 10.24 & 2.1 & 5.25 \\
Human Capital & 26 & 22 & 23 & 71 \\
& 23.64 & 13.25 & 16.08 & 16.95 \\
Human Health & 17 & 16 & 18 & 51 \\
& 15.45 & 9.64 & 12.59 & 12.17 \\
Industry & 23 & 32 & 40 & 95 \\
& 20.91 & 19.28 & 27.97 & 22.67 \\
Nuclear Safety & 4 & 8 & 7 & 19 \\
& 3.64 & 4.82 & 4.9 & 4.53 \\
Nuclear Science & 15 & 35 & 22 & 72 \\
& 13.64 & 21.08 & 15.38 & 17.18 \\
\hline Total & 4 & 15 & 14 & 33 \\
& 3.64 & 9.04 & 9.79 & 7.88 \\
\hline
\end{tabular}

Source: Data from AFRA, ARCAL and RCA (Some projects fall under two categories).

As there is no centralized authority in NEST networks, cross-national projects are negotiated and designed by participants working across borders. An ARCAL coordinator at the National Commission of Atomic Energy in Argentina explains how bureaucrats in domestic NEST institutions promote their own research agendas in the region:

Each country has certain national priorities within its own (nuclear) institutions and the project ideas come from there...we present these ideas, just like the other countries and if there is a consensus, that is, if there is a minimum of four countries that have presented similar projects in the area, they get together and move forward (interview with ARCAL liaison for Argentina. 2006).

Disparities between skillsets of state professionals across the Global South affect their participation in cross-national projects. As representative of the African network explains, gaps in NEST knowledge shape the quality of and access to collective training: 
There is not a critical mass of new students every year to be trained and to go out because the nuclear sector [in Africa] is very small. Today there are only 6 countries that have this kind of training: Algeria, Morocco, Egypt, Ghana, Nigeria, South Africa. So all these countries can train their people, but they do it in their own way. So, AFRA brought them together. They discuss the needs for developing training in higher education and to harmonize one curriculum for a master degree in nuclear science and technology for Africa. It is not nuclear technology like Europe; Europe has a master degree in nuclear technology for nuclear power, but African countries the majority of them will not accede to nuclear power so the issue is much more for socioeconomic development, for nuclear power applications (interview with Program Manager for AFRA, June 2007).

Given that keeping skills current and staying abreast of technological change is critical to these bureaucrats and their agencies, significant training time is spent on mastering new techniques through computer simulations, research and development activities, workshops and symposia. Project-based networks serve as effective and far-reaching mechanisms of technology transfer by, as one AFRA manager put it, "train(ing) the trainers" (interview with Program Manager for AFRA, June 2007.). A rare inter-regional nuclear project illustrates the phenomenon. In 1999, nuclear bureaucrats from Argentina, Egypt, Malaysia, Morocco, Pakistan, the Philippines and Uruguay participated in a pilot program to test the effectiveness of distance learning as a means to train technicians in radioisotope and radiation oncology treatments. Once experts from these countries were fully trained, they were sent back to distribute the acquired information and train their professional peers in their respective regions IAEA n.d.). Interagency networks transform existing state infrastructures, like research centers and laboratories, into regional training hubs. As the AFRA liaison explains:

We have 10 centers in radiotherapy, radiation safety, biotechnology and instrumentation. All these centers are in different countries, the majority in South Africa of course, but we have two in Egypt, one in Tunisia, one in Morocco and one in Algeria. These centers provide, training, advisory assistance, some in South Africa provide training to the other centers and to this program. They train people, short term or long term (interview with Program Manager for AFRA, June 2007).

\section{Visualizing NEST Networks}

The data from AFRA, ARCAL and RCA projects allows us to map the relative proximity of different countries and agencies, a critical first step to visualize collaboration, partner selection and homophily trends. In the last fifteen years, political scientists have devised a very large number of strategies to translate collaborative decisions into conceptual maps that assess proximity among agents (Bafumi, et al. 2005; Poole 2005; Treier and Jackman 2008). Many of 
these advances have come from social network analysis, with a variety of tools available to identify the ties (edges) between actors (nodes). A collective view of NEST collaboration is displayed in Figure 1, which depicts project-agency ties among countries within the three regions of the developing world (while interregional projects in NEST exist, they are very infrequent). In this figure, circles denote countries while lines reflect the links between national agencies. Projects and colors reveal „community structures" which are "densely connected subgraphs."13 For these graphs, I included all participating agency-countries, even those who participated infrequently, such as Trinidad and Tobago (TTO) and Barbados (BRB) in ARCAL. Thus, the visualized AFRA network has 35 nodes and 595 edges; RCA, 33 and 450; and ARCAL, 25 and 276 respectively.

\section{Figure 1: Regional Networks of Inter-Agency Collaboration in NEST}

AFRA - Density: 1

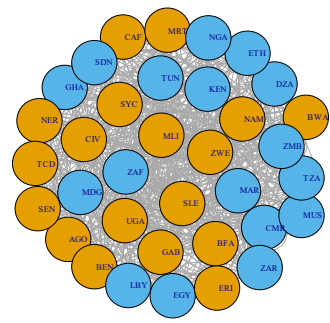

RCA - Density: 0.852

ARCAL - Density: 0.92

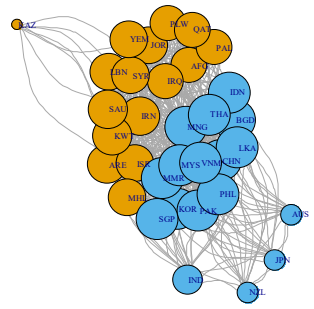

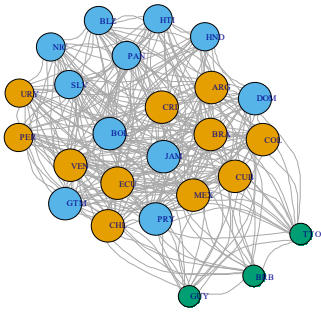

Note: Three collaborative networks in Asia (RCA), Africa (AFRA) and Latin America (ARCAL) with density scores. Some Middle Eastern and donor countries also participate in NEST projects, however marginally and thus are represented in these networks. Visualization done in $\mathrm{R}$ with the Fructerman-Reingold layaout algorithm.

The density scores (or the proportion of potential ties in a network that are actually present) of AFRA (1), RCA (.85) and ARCAL (.92) are very high, indicating that participating bureaucrats and their agencies have collaborated with most (if not all, as in the case of the African network) regional neighbors during the observation period. Closer examination reveals the most frequent ties among equally developed nuclear programs. For example, in the ARCAL network we can see that most NEST agencies of South America-at similar levels of development and from countries with close ties-are in the same "community." Mexico, one of the only three nuclear energy producers of the region, together with Argentina and Brazil, also appears closer in collaboration with the NEST programs of the Southern Cone. While illustrative, however, this descriptive information provides little insight into the determinants of inter-

13 I use country and agency interchangeably as the institution with primary jurisdiction over NEST policy leads the country's participation in IAEA-sponsored projects. For community structures, see Baron (n.d.). 
agency cooperation within the NEST networks of Africa, Latin America and Asia. In the next section I introduce a variety of statistical models to explain international inter-agency cooperation.

\section{EXPLAINING INTERNATIONAL INTER-AGENCY COOPERATION IN NEST}

In this section, I test my skill-based theory of inter-agency cooperation using the cross-national co-sponsorship NEST data described above. I consider three different yet interrelated decision problems. First, I conceptualize the participation model as an individual agency choice to join NEST projects. I estimate a variety of models that answer the question: why does a state agency decide to participate in international NEST projects? I assume that participation may be decided independently from the pool of available partners and that country agencies may differ in their mean propensity to engage in NEST projects as a function of the economic resources and prior skill levels they have, as well as other domestic factors, such as a state's regime type or its openness to trade. Second, I conceptualize the participation decision as a partner selection problem. That is, I answer the question asked by expert bureaucrats: which foreign agency is a suitable partner for my agency? This second set of dyadic models is concerned with the type of traits that make a state agency more attractive as a potential partner. Finally, I conceptualize the participation decision as a network collaboration problem. That is, I answer the question: what type of collective effort will provide the highest returns to the skills of my agency? To answer this last question, I estimate Exponential Random Graph Models (ERGM) for social network analysis, which allows me to measure cooperation as a decision within the full NEST network forged by the 69 countries of the sample.

\section{The Dependent Variables}

The three different sets of models require different treatments of the data. In its simplest form, the decision to participate takes the value of 1 if a country joins a project and 0 otherwise. In this case, I use logistic models to analyze the decision by a state nuclear agency to participate in cross-national projects in NEST. In the dyadic models, the dependent variable takes the value of 1 if a pair of countries is jointly participating in a project and 0 otherwise. This second dataset incorporates information about the degree of similarity/ difference among potential agency partners in terms of scientific and technical endowments. Finally, the third set of models takes an affiliation matrix as the dependent variable, where every cell describes the number of times that each pair of countries collaborated in projects. ${ }^{14}$ 
Data is organized by country, year and project, allowing for model specifications that control for within and across program variation. For the first set of models, measuring program participation, the data covers 158 projects from Latin America (ARCAL), 119 projects from Africa (AFRA) and 186 projects from Asia (RCA) implemented between 1984 and 2008. ${ }^{15}$ Because countries within each region are eligible to participate in these programs, the full dataset includes 4,266 observations in Latin America; 4,403 in Africa; and 6,138 observations in Asia. In all, models are estimated using this large cross-sectional dataset that covers 14,807 total observations across the globe. Given the cross-sectional time series nature of the data, a variety of different models were estimated, including specifications with fixed effects and random effects that control by year and country effects.

For the second set of models, testing for partner selection, I reshape the participation dataset to create country dyads and measure homophily traits among potential partners. Reshaping the data to form dyadic pairs makes for a very large dataset, with over 498,000 observations. Consequently, models are estimated with clustered errors by dyadic partners (i.e. 3,000+ dyadic partners). Finally, for the third set of models, the dependent variable is the affiliation matrix that describes the number of times that each country collaborates with another.

\section{Independent Variables}

The main covariates used to explain the decision to participate are: the percentage of government spending over total GDP; the level of skill of the state agency, whether technical or political (technical agency), and the degree of specialization in nuclear policy (nuclear agency); the overall pool of scientific skills of a country, as determined by their total publication output in scientific journals (number of scientific publications); and the type of skill (general or specific) that is promoted in each cross-national project (project skill content). ${ }^{16}$ Government spending data was obtained from the Penn World Table Version 7.1. My theory predicts that government increased spending will produce a corresponding decrease in international project participation (Hypothesis 1). It also predicts that higher levels of skills will have a positive effect on project participation (Hypothesis 2). Thus, I expect the variables Technical Agency, Nuclear Agency (which I coded) and Number of Scientific Publications, to increase inter-agency cooperation. To

15 Data also includes Middle Eastern and East European countries, but their participation in NEST projects is recent and almost negligible compared to the rate of participation of African, Asian and Latin American agencies.

16 The World Bank defines the variable Scientific and Technical Journal Articles as "the number of scientific and engineering articles published in the following fields: physics, biology, chemistry, mathematics, clinical medicine, biomedical research, engineering and technology and earth and space sciences." It is one of the few indicators of the size and quality of national scientific communities that has data for all the countries included in the present study. My expectation is that the higher the level of skills of a country, the greater its scientific publication output should be. 
create „Project Skill Content” I classified all NEST projects based on the type of training they offered to members. The variable takes the value of 1 if the project transfers general skills and 0 otherwise. Given Becker's (2009) expectations regarding employers' disincentives to pay the cost of general skills acquisition for employees, I anticipate that bureaucrats will seek NEST projects that offer general (rather than specialized) training.

A number of controls were also included in the models, such as countries' investment and consumption as percentages of GDP (World Penn Tables); the number of (international) technical cooperation agreements signed by the country; the total amount of multilateral financing allocated to each country in the year that the project was initiated; the total size of the economy of a country as described by the GDP; exposure to international trade (openness); the total population; and the Polity IV score with a range of -10 to 10 , whereby fully autocratic regimes takes the value of -7 and fully democratic ones takes the value of 7 or above.

In the dyadic and network models, in order to measure the extent to which countries with similar levels of technological development are more likely to collaborate, I consider the absolute difference between the number of technical publications of the scientific communities (difference in total scientific publications) of each pair of countries $[j, z]$, that is: ABS(NPublications [ $j]-$ NPublications $[z])$. As controls, I also consider the absolute difference in the number of technical cooperation agreements signed by each pair of countries $[j, z]$ and the difference in GDP of each pair of countries. I expect programs with similar scientific communities to be more likely to collaborate as expert bureaucrats seek to pool resources with true peers.

\section{Participation Models: Discussion}

Table 2 presents the results of the participation models, which estimate the probability that a country will join collaborative projects in NEST. In all three specifications, which include different sets of covariates, the key variables of interest consistently behave as expected. Government spending is negative and statistically significant, with a one percent increase reducing the odds ratio of participation in a NEST projects between $2 \%$ and $5 \%$. The effect is both statistically and substantively important. For example, between 1983 and 1989, government spending in Brazil declined by four points, from 19.2\% of GDP to $14.97 \%$, which should yield a corresponding $17 \%$ increase in the odds-ratio of collaborating in ARCAL projects. Separate models for each of the different regions provide further support for the proposed hypothesis, with government spending having larger effects in Asia and more moderate ones in Africa.

Results also show support for a skill driven theory of inter-agency cooperation, whereby projects that transfer general skills significantly increase the likelihood of participation in NEST. As expected, more technical agencies have higher rates of participation in NEST projects. In all models, the variable 
nuclear agency is positive and significant, showing that sectors that are led by a technical nuclear agency-rather than by other non-nuclear agenciesincrease the odds of participation in NEST by approximately $80 \%$. The variable that describe the skill levels of the national scientific community also provide support for Hypothesis 2, which expects agencies from countries with a higher level of skills to cooperate more in NEST networks. Each unit of increase in the number $(\log )$ of scientific publications increases the odds of participation in cross-national projects by $16 \%$ and $25 \%$, $\exp (.154)$ and $\exp (.227)$.

Table 2: Participation in NEST Projects

\begin{tabular}{|c|c|c|c|}
\hline & Model A & Model B & Model C \\
\hline \multirow{2}{*}{ Technical Agency } & $1.259^{* * *}$ & 0.399 & -0.184 \\
\hline & $(0.3014)$ & $(0.5039)$ & $(0.4915)$ \\
\hline \multirow{2}{*}{ Nuclear Agency } & $0.547^{* *}$ & 0.646 & 0.477 \\
\hline & $(0.2374)$ & $(0.4144)$ & $(0.3931)$ \\
\hline \multirow{2}{*}{ Government Spending (\%) } & $-0.044^{* * *}$ & $-0.027^{* * *}$ & $-0.013^{* *}$ \\
\hline & $(0.0058)$ & $(0.0076)$ & $(0.0077)$ \\
\hline \multirow{2}{*}{ Investment (\%) } & 0.005 & $0.02^{* * *}$ & $0.013^{* *}$ \\
\hline & $(0.0049)$ & $(0.0062)$ & $(0.0065)$ \\
\hline \multirow{2}{*}{ Consumption (\%) } & -0.001 & $0.007^{*}$ & $0.012^{* * *}$ \\
\hline & $(0.0035)$ & $(0.0044)$ & $(0.0046)$ \\
\hline \multirow{2}{*}{ Project Skill Content } & $0.592^{* * *}$ & $0.638^{* * *}$ & $0.593^{* * *}$ \\
\hline & $(0.0443)$ & $(0.0506)$ & $(0.0515)$ \\
\hline \multirow{2}{*}{ Multilateral Financing } & & 0.014 & $0.024^{*}$ \\
\hline & & $(0.0119)$ & $(0.0129)$ \\
\hline \multirow{2}{*}{$\begin{array}{l}\text { Number of } \quad \text { Scientific } \\
\text { Publications (LN) }\end{array}$} & & $0.264^{* * *}$ & 0.087 \\
\hline & & $(0.0558)$ & $(0.0730)$ \\
\hline \multirow{2}{*}{$\begin{array}{l}\text { Number of Technical } \\
\text { Cooperation Agreements }\end{array}$} & & $-0.223^{* * *}$ & $-0.319^{* * *}$ \\
\hline & & $(0.0779)$ & $(0.0758)$ \\
\hline \multirow{2}{*}{ Asia } & & -0.793 & $-1.115^{* *}$ \\
\hline & & $(0.4865)$ & $(0.4687)$ \\
\hline \multirow{2}{*}{ Latin America } & & $-2.599 * * *$ & $-2.61^{* * *}$ \\
\hline & & $(0.3633)$ & $(0.3501)$ \\
\hline \multirow{2}{*}{ GDP (LN) } & & & $0.478^{* * *}$ \\
\hline & & & $(0.1254)$ \\
\hline \multirow{2}{*}{ Openness } & & & -0.002 \\
\hline & & & $(0.0019)$ \\
\hline
\end{tabular}




\begin{tabular}{lrrr}
\hline & Model A & Model B & \multicolumn{1}{c}{ Model C } \\
\hline Population (LN) & & & $0.374^{* * *}$ \\
& & & $(0.1396)$ \\
Polity Score & & & $0.005^{* *}$ \\
& & & $(0.0025)$ \\
Constant & $-0.941^{* *}$ & 2.204 & -1.696 \\
& $(0.4340)$ & $(1.4722)$ & $(2.1000)$ \\
Alpha(LN) & -0.11 & $0.633^{* *}$ & $0.464^{*}$ \\
N & $(0.1695)$ & $(0.2660)$ & $(0.2778)$ \\
Groups & 11320 & 8842 & 8398 \\
\hline
\end{tabular}

Note: Cross-Sectional time series regression models with random effects by country. Baseline region is Africa. Standard errors in parentheses with confidence levels reported as follows: ${ }^{*} \mathrm{p}<0.1,{ }^{* *} \mathrm{p}<0.05,{ }^{* * *} \mathrm{p}<0.01$.

Another important fact is that additional resources accrued through international technical cooperation agreements reduce collaboration in NEST projects. In addition to these initial findings, and outside of the expectations derived from my skill-driven theory, there are some interesting results with regards to some of the control variables. Table 2 shows that larger, more democratic and more economically-developed countries are more active collaborators in the NEST networks as shown by the population, Polity and GDP variables. However, while the effects of population and GDP are both substantively and statistically significant, the substantive effect of democracy, by contrast, is rather small.

\section{Dyadic Models: Discussion}

Participation models do not wholly explain why some agencies are more sought after as potential partners than others, or why some partnerships are more durable. To test for partner selection in NEST collaboration, Table 3 estimates dyadic models that take the value of 1 if a pair of countries works together in a NEST project and 0 otherwise and incorporate information about the relative similarity/dissimilarity between potential partners. As described before, the models include all covariates from Table 2 and also three new terms that test for homophily/heterophily with measures of inter-country differences in total number of scientific publications, international technical agreements and GDP. While these independent variables are based on the difference for each dyad of state agencies, they can be used as inter-country measures of similarities (i.e. homophily) by interpreting them correctly (e.g., the greater the difference between two countries, the less likely they should be willing to cooperate; conversely, the lesser the difference, the more they should be to seek each other out). 
Table 3: Joint Participation in NEST Projects

\begin{tabular}{|c|c|c|c|c|}
\hline & & Model A & Model B & Model C \\
\hline \multirow{10}{*}{ 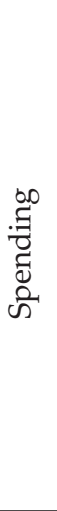 } & \multirow[t]{2}{*}{ Government Spending (\%) } & $-0.056^{* * *}$ & $-0.029^{* * *}$ & $-0.018^{* * *}$ \\
\hline & & $(0.0010)$ & $(0.0012)$ & $(0.0014)$ \\
\hline & \multirow{2}{*}{ Investment (\%) } & $0.002^{* * *}$ & $0.014^{* * *}$ & $0.014^{* * *}$ \\
\hline & & $(0.0008)$ & $(0.0011)$ & $(0.0014)$ \\
\hline & \multirow{2}{*}{ Consumption (\%) } & $-0.008^{* * *}$ & $0.008^{* * *}$ & $0.011^{* * *}$ \\
\hline & & $(0.0006)$ & $(0.0007)$ & $(0.0009)$ \\
\hline & \multirow{2}{*}{ Asia } & $-0.403^{* * *}$ & $0.235^{* * *}$ & $-0.207^{* *}$ \\
\hline & & $(0.0571)$ & $(0.0575)$ & $(0.0809)$ \\
\hline & \multirow{2}{*}{ Africa } & $-0.686^{* * *}$ & $-0.189^{* * *}$ & $-0.293^{* * *}$ \\
\hline & & $(0.0642)$ & $(0.0485)$ & $(0.0572)$ \\
\hline \multirow{8}{*}{ 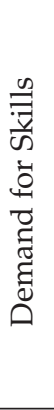 } & \multirow{2}{*}{ Technical Agency } & & $1.169^{* * *}$ & $0.744^{* * *}$ \\
\hline & & & $(0.0629)$ & $(0.0827)$ \\
\hline & \multirow{2}{*}{ Nuclear Agency } & & $0.207^{* * *}$ & 0.091 \\
\hline & & & $(0.0481)$ & $(0.0570)$ \\
\hline & \multirow{2}{*}{ Proyect Skill Content } & & $0.627^{* * *}$ & $0.777^{* * *}$ \\
\hline & & & $(0.0089)$ & $(0.0107)$ \\
\hline & \multirow{2}{*}{$\begin{array}{l}\text { Number of Scientific Publi- } \\
\text { cations (LN) }\end{array}$} & & $0.226^{* * *}$ & $0.129^{* * *}$ \\
\hline & & & $(0.0084)$ & $(0.0141)$ \\
\hline \multirow{12}{*}{ 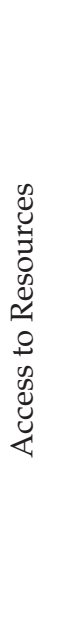 } & \multirow{2}{*}{ Multilateral Financing } & & $0.009^{* * *}$ & $0.007^{* *}$ \\
\hline & & & $(0.0020)$ & $(0.0032)$ \\
\hline & \multirow[t]{2}{*}{$\begin{array}{l}\text { Number of Technical Coo- } \\
\text { peration Agreements }\end{array}$} & & $-0.103^{* * *}$ & $-0.183^{* * *}$ \\
\hline & & & $(0.0132)$ & $(0.0159)$ \\
\hline & \multirow{2}{*}{ GDP (LN) } & & & $0.289^{* * *}$ \\
\hline & & & & $(0.0253)$ \\
\hline & \multirow{2}{*}{ Openness } & & & -0.0002 \\
\hline & & & & $(0.0004)$ \\
\hline & \multirow{2}{*}{ Population (LN) } & & & $0.431^{* * *}$ \\
\hline & & & & $(0.0249)$ \\
\hline & \multirow{2}{*}{ Polity Score } & & & $0.0076^{* * *}$ \\
\hline & & & & $(0.0020)$ \\
\hline
\end{tabular}




\begin{tabular}{|c|c|c|c|c|}
\hline & & Model A & Model B & Model C \\
\hline \multirow{6}{*}{ 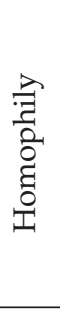 } & Difference in Total Scientific & & & $-0.098^{* * *}$ \\
\hline & Publications (LN) & & & $(0.0098)$ \\
\hline & & & & 0.004 \\
\hline & Difference in GDP & & & $(0.0221)$ \\
\hline & Difference in Technical Coo- & & & -0.07 \\
\hline & peration Agreements & & & $(0.0606)$ \\
\hline & & $1.019^{* * *}$ & $-0.933^{* * *}$ & $-5.216^{* * *}$ \\
\hline & Constant & $(0.0633)$ & $(0.2368)$ & $(0.3899)$ \\
\hline & Sirma (11) & $0.585^{* * *}$ & $-0.259^{* * *}$ & $-0.331^{* * *}$ \\
\hline & sigma(u) & $(0.0285)$ & $(0.0357)$ & $(0.0422)$ \\
\hline & & $0.353^{* * *}$ & $0.19^{* * *}$ & $0.179^{* * *}$ \\
\hline & Rho & & $(0.0055)$ & $(0.0062)$ \\
\hline & $\mathrm{N}$ & 489650 & 286260 & 198750 \\
\hline & Groups & 3058 & 2244 & 1676 \\
\hline & LogLik & -265488 & -163074.09 & -113603.42 \\
\hline
\end{tabular}

Note: Cross-sectional time series regression models with random effects by collaborative dyad. Baseline region is Latin America. Standard errors in parentheses with confidence levels reported as follows: ${ }^{*} p<0.1,{ }^{* *} p<0.05$, *** $\mathrm{p}<0.01$. $_{\mathrm{T}}$

Table 3 presents three models of joint collaboration: a restricted model measuring the effect of government spending (Model A); a skill model, testing for the effect of government spending as well as for the relative skill endowment of the expert agency (Model B); and an unrestricted specification that also includes the three similarity/dissimilarity terms. I expect differences in the level of development of the national scientific community (as described by differences in the number of its publications) and differences in the adoption of international technical treaties to reduce cooperation. Finally, I consider differences in GDP as a placebo control, given that it should not affect the level of cooperation.

Overall, models in Table 3 are consistent with those presented in Table 2. The effect of government spending on joint collaboration is negative and statistically significant, once again supporting Hypothesis 1. Every 1\% increase in government spending decreases the odds of collaboration between in Model A to in Model C. Countries with technical agencies and/or nuclear agencies are also more likely to cooperate, with the effect being very large and statistically significant for the technical agency and more modest for the nuclear one.

Parameters that describe different skill effects are large and statistically significant, with projects that transfer general skills being more likely to elicit cooperation, and more developed scientific communities being more active partners. Indeed, the total number of scientific publications (LN) of a community increases the odds of cooperation by $25 \%$ in Model B-i.e. $\exp (.226)$ - and $14 \%$ in 
Model C-i.e. $\exp (.129)$. Model results for the homophily parameters are in the expected direction, although only the parameter describing differences in the number of scientific publications reaches statistical significance. A one unit increase in the logged differences in scientific publications between each pair of countries $[\mathrm{i}, j]$ results in a decline of almost $9 \%$ in the odds of cooperation. ${ }^{17}$

Figure 2: Effect of Government Spending and Homophily on Participation in NEST Projects

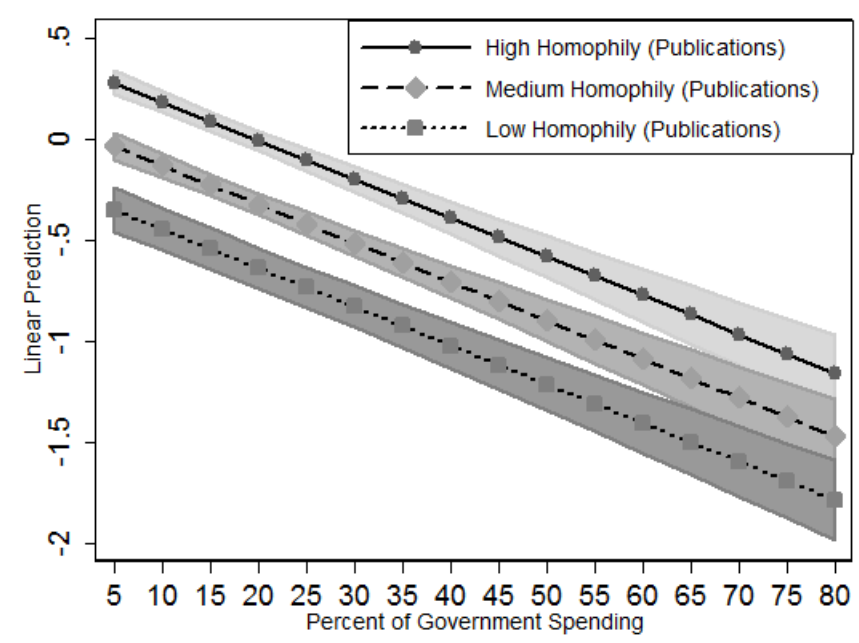

Note: Plots describe marginal effects of government spending on the decision to participate in cross-national NEST projects with all other covariates set to their means. The different lines reflect differences in inter-agency homophily.

Figure 2 describes the marginal effect of government spending on program participation for three different levels of homophily (low, medium and high). The effect of government spending is negative and statistically significant, with joint participation for a pair of countries being more likely when their respective programs are at similar levels of development. At very low levels of government spending $(5 \%)$, the probability of joint participation for countries with very similar scientific communities is roughly $57 \%$ i.e. $\operatorname{Pr}(1 \mid \mathrm{x})=\operatorname{inv} \log i t(.27)=0.57$. By contrast, the probability of joint participation when there are significant differences in program homophily is seventeen points lower, roughly $40 \%$ i.e., $\operatorname{Pr}(1 \mid \mathrm{x})=$ invlogit $(-.4)=0.401$.

17 This variable measures the log of the absolute differences in the rate of publications by the scientific community of each country as measures by the World Bank and described in the previous section. The variable describing the difference in the total number of scientific publications of countries is computed as: , with a range of $[0,10.95]$. 


\section{Exponential Random Graph Models (ERGM): Discussion}

Inow measure the extent to which the study's covariates explain collaboration in NEST networks. To estimate the number of ties between each pair of countries, I estimate ERGM for valued networks. These models allow researchers to describe the number of edges (collaborative instances) between each pair of countries as a function of covariates and by taking into account network structure. The underlying Poisson distribution of the valued ERGM allows readers to interpret the coefficients as logged units of change in the number of times that each pair of country collaborates. For example, Model C in Table 4 shows that each percent increase in government spending results in a $-0.9 \%$ decline in the number of instances of collaboration between countries e.g. .

Table 4: Exponential Random Graph Models of Nuclear Cooperation, Valued Network

\begin{tabular}{|c|c|c|c|c|}
\hline & & Model A & Model B & Model C \\
\hline \multirow{4}{*}{ 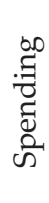 } & 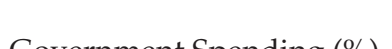 & & $-0.00835^{* * *}$ & $-0.01009^{* * *}$ \\
\hline & 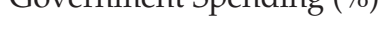 & & $(0.0003)$ & $(0.0003)$ \\
\hline & & & & $-0.13964^{* * *}$ \\
\hline & GDI (LN) & & & $(0.0032)$ \\
\hline \multirow{10}{*}{ 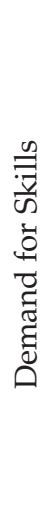 } & Number of Scientific & $0.05094^{* * *}$ & $0.10269^{* * *}$ & $0.08528^{* * *}$ \\
\hline & Publications (LN) & $(0.0020)$ & $(0.0010)$ & $(0.0016)$ \\
\hline & 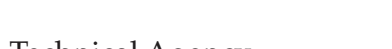 & & & $0.08481^{* * *}$ \\
\hline & Iecnnical Agency & & & $(0.0084)$ \\
\hline & Nuclear Agency & & & $0.23411^{* * *}$ \\
\hline & & & & $(0.0068)$ \\
\hline & & & & $0.04413^{* * *}$ \\
\hline & Multilateral Financing & & & $(0.0017)$ \\
\hline & Number of Technical & & & 0.01362 \\
\hline & Cooperation Agreements & & & $(0.0024)$ \\
\hline
\end{tabular}




\begin{tabular}{llccc}
\hline & Model A & Model B & Model C \\
\hline & Difference in Total Scientific & $-0.10248^{* * *}$ & $-0.05319^{* * *}$ & $-0.03355^{* * *}$ \\
Publications (LN) & $(0.0020)$ & $(0.0018)$ & $(0.0021)$ \\
& & & $-0.15594^{* * *}$ & $-0.12440^{* * *}$ \\
& Difference in GDP & & $(0.0041)$ & $(0.0041)$ \\
& & 0.02805 & $0.26991^{* * *}$ & $0.37712^{* * *}$ \\
& & $(0.0174)$ & $(0.0129)$ & $(0.0125)$ \\
& & $0.02756^{*}$ & $0.39781^{* * *}$ & $0.29493^{* * *}$ \\
& & $(0.0111)$ & $(0.0094)$ & $(0.0121)$ \\
Same Region (RCA) & -0.01250 & $0.10752^{* * *}$ & $0.17385^{* * *}$ \\
& $(0.0110)$ & $(0.0107)$ & $(0.0118)$ \\
\hline Sum (Constant) & $-0.00835^{* * *}$ & $-0.00835^{* * *}$ & $-0.00835^{* * *}$ \\
& $(0.0003)$ & $(0.0003)$ & $(0.0003)$ \\
\hline DF & 4278 & 4278 & 4278 \\
BIC & -163454 & -168838 & -174424 \\
AIC & -163492 & -168889 & -174507 \\
\hline
\end{tabular}

Note: ERGM estimates of collaboration in valued-network, with a Poisson distribution. Models estimated using CRAN ergm.count in R 3.0.2.

As in previous models, we can observe that higher levels of skills, greater number of scientific publications and technical and nuclear state agencies are associated with more inter-agency cooperation. A one percent increase in the total number of scientific publications results in an $8.3 \%$ increase in the probability of cooperation. Similarly, a program led by a nuclear state agency increases the number of collaborative instances by $25.8 \%$. Homophily estimates also strongly support the proposed theory, with larger differences in the number of publications of a pair of agencies reducing the number of instances of collaboration. The effects are large, with every unit of increase in dissimilarity yielding reductions from $9.5 \%$ in model A to $3.3 \%$ in model C. Greater differences in the overall GDP level also result in large and significant declines in the number of instances of collaboration. In all, the greater the difference in skill and size between national programs, the less likely they are to cooperate. Finally, mix-and-match results show that, once we control for all covariates, the network of collaboration is denser in Latin America (ARCAL) and sparser in Asia (RCA). 


\section{CONCLUSION}

Why do bureaucrats from developing countries-with scarce resources and chronic budget deficits-cooperate internationally? My theory of international inter-agency cooperation offers a precise mechanism to explain why state professionals in the Global South collaborate across borders. What explains these networks of international cooperation, I argue, is the individual decision by expert bureaucrats to take investment in skill upgrading in their own hands when governments cut funding. Networking with foreign peers is a key strategy to access needed resources. In fact, as the previous sections showed, bureaucrats from NEST agencies in the developing world cooperate abroad more when government spending at home decreases (Hypothesis 1). But not all bureaucrats face the same barriers to access. As these findings confirm, preexisting levels of expertise determine the ability of a state agency to collaborate with peer institutions (Hypotheses 2 and 3). Transgovernmental collaboration in the Global South is more likely to develop between bureaucrats at higher skill levels, and when NEST agencies with lower levels of expertise do cooperate they tend to do so with equally disadvantaged institutions (i.e. homophily).

Given these findings, future research should consider the possible effects of transgovernmental cooperation on bureaucratic expertise. Anecdotal data and elite interviews confirm that accessing international resources has a strong impact on the career path of individual bureaucrats, hence their incentive to seek out cross-border partnerships with peers. An intriguing and promising line of future research is to measure the impact of this strategy on the state's institutional expertise.

Finally, Slaughter posited in 2004 that international networks of state experts have the potential to deepen global governance by offering a more transparent and democratic alternative to the high politics of government-to-government negotiations. Without doubt, cooperation across borders forces disclosure. In few policy domains is this more relevant than in NEST, where security concerns tend to run high because of sensitive or dual technology, which can be used for both military and civilian purposes. Region-wide, project-based cooperation in this area forces disclosure and transparency. By working together, expert bureaucrats and their agencies develop personal ties with their foreign peers, which in turn help build trust across participating actors and lower future transaction costs. 


\section{REFERENCES}

Adler, Emanuel. 2008. "The Spread of Security Communities: Communities of Practice, Self-Restraint, and Nato's Post-Cold War Transformation". European Journal of International Relations 14(2): 195-230.

Alcañiz, Isabella. 2010. “Bureaucratic Networks and Government Spending: A Network Analysis of Nuclear Cooperation in Latin America". Latin American Research Review 45(1): 148-172.

2016. "Partner Selection in International Environmental Networks: The Effect of Skills and Money on Cooperation in the Global South". Environmental Science E Policy 55(1): 107-115.

Alemán, Eduardo and Ernesto Calvo. 2013. "Explaining Policy Ties in Presidential Congresses: A Network Analysis of Bill Initiation Data". Political Studies 61(2): 356-377.

Almeida, Celia, R. Pires de Campos, Paulo Buss, J. R. Ferreira and L. E. Fonseca. 2010. “Brazil's Conception of South-South 'Structural Cooperation' in Health". RECIIS Revista Eletrônica de Comunicação, Informação \& Inovação em Saúde 4(1): 23-32.

Bach, David, and Abraham L. Newman. 2014. "Domestic Drivers of Transgovernmental Regulatory Cooperation". Regulation \& Governance 8(4): 395-417.

Bach, David, and Abraham L. Newman. 2010. "Transgovernmental Networks and Domestic Policy Convergence: Evidence from Insider Trading Regulation". International Organization 64(3): 508-528.

Bafumi, Joseph, Andrew Gelman, David K. Park and Noah Kaplan. 2005. "Practical Issues in Implementing and Understanding Bayesian Ideal Point Estimation". Political Analysis 13(2): 171-187.

Baron, Jonathan. n.d. "Community structure detecting based on the leading eigenvector of the community matrix". Retrevied from http://finzi.psych.upenn.edu/library/igraph/ html/cluster_leading_eigen.html.

Bauer, Steffen. 2006. "Does Bureaucracy Really Matter? The Authority of Intergovernmental Treaty Secretariats in Global Environmental Politics". Global Environmental Politics 6(1): 23-49.

Becker, Gary S. 2009. Human Capital: A Theoretical and Empirical Analysis, with Special Reference to Education. Chicago: University of Chicago Press.

Bendor, Jonathan, and Adam Meirowitz. 2004. "Spatial Models of Delegation". American Political Science Review 98(2): 293-310.

Biermann, Frank, and Bernd Siebenhüner. 2009. Managers of Global Change: The Influence of International Environmental Bureaucracies. Cambridge: MIT Press.

Blais, André, and Stéphane Dion. 1990. "Are Bureaucrats Budget Maximizers? The Niskanen Model \& Its Critics". Polity 22(4): 655-674.

Brown, Phillip, Andy Green and Hugh Lauder. 2001. High Skills: Globalization, Competitiveness, and Skill Formation. New York: Oxford University Press.

Campion, Patricia, and Wesley Shrum. 2004. "Gender and Science in Development: Women Scientists in Ghana, Kenya, and India". Science, Technology \& Human Values 29(4): 459485.

Carpenter, Daniel P. 2001. The Forging of Bureaucratic Autonomy: Reputations, Networks, and Policy Innovation in Executive Agencies, 1862-1928. Princeton: Princeton University Press.

Chwieroth, Jeffrey M. 2007. "Testing and Measuring the Role of Ideas: The Case of Neoliberalism in the International Monetary Fund". International Studies Quarterly 51(1): 5-30.

Danziger, James N. and Kim Viborg Andersen. 2002. “The Impacts of Information Technology on Public Administration: An Analysis of Empirical Research from the 'Golden Age' of Transformation". International Journal of Public Administration 25(5): 591-627.

Elliott, Lorraine. 2012. "Asean and Environmental Governance: Strategies of Regionalism in Southeast Asia". Global Environmental Politics 12(3): 38-57.

Ericsson, K. Anders. 2006. "The Influence of Experience and Deliberate Practice on the Development of Superior Expert Performance". In The Cambridge Handbook of Expertise and 
Expert Performance, edited by K Anders Ericsson, Neil Charness, Paul J. Feltovich and Robert R. Hoffman. New York: Cambridge University Press, 683-703.

Estevez-Abe, Margarita, Torben Iversen and David Soskice. 2001. "Social Protection and the Formation of Skills: A Reinterpretation of the Welfare State". In Varieties of Capitalism: The Institutional Foundations of Comparative Advantage, edited by Peter A Hall and David Soskice. New York: Oxford University Press, 145-183.

Gailmard, Sean. 2002. "Expertise, Subversion, and Bureaucratic Discretion". Journal of Law, Economics, and Organization 18(2): 536-555.

Gailmard, Sean, and John W. Patty. 2013. Learning While Governing: Expertise and Accountability in the Executive Branch. Chicago: University of Chicago.

Haas, Peter M. 1992. "Introductions: Epistemic Communities and International Policy Coordination". International Organization 46(1): 1-35.

Heclo, Hugh. 1978. "Issue Networks and the Executive Establishment". In The New American Political System, edited by Anthony King. Washington, DC: American Enterprise Institute for Public Policy Research, 87-124.

Herrera, Yoshiko M. 2010. Mirrors of the Economy: National Accounts and International Norms in Russia and Beyond. Ithaca Cornell University Press.

Hicks, Robert L., Bradley C. Parks, J. Timmons Roberts and Michael J. Tierney. 2008. Greening Aid? Understanding the Environmental Impact of Development Assistance. New York: Oxford University Press.

Hoffer, Adam J. 2013. Bureaucratic Behavior: Budget Cuts, Imperfect Information, and the 2013 Sequester. Social Science Research Network.

Huber, John D. and Charles R. Shipan. 2002. Deliberate Discretion? The Institutional Foundations of Bureaucratic Autonomy. New York: Cambridge University Press.

Huber, John D. 2006. "Politics, Delegation, and Bureaucracy". In The Oxford Handbook of Political Economy, edited by Barry R. Weingast and Donald A. Wittman. New York: Oxford University Press, 256-272.

International Atomic Energy Agency. n.d. "Technical Cooperation". Retrieved from https:// www.iaea.org/technicalcooperation/Home/index.html.

International Atomic Energy Agency. 2015. "Regional/Cooperative Agreements". Retrieved from https://www.iaea.org/technicalcooperation/Partnerships/Reg-Coop-Agreements.html.

Jordana, Jacint, David Levi-Faur and Xavier Fernández i Marín. 2011. “The Global Diffusion of Regulatory Agencies: Channels of Transfer and Stages of Diffusion". Comparative Political Studies 44(10): 1343-1369.

Kahler, Miles. 2000. "Legalization as Strategy: The Asia-Pacific Case". International Organization 54(3): 549-571.

Keohane, Robert O., and Joseph S. Nye. 1974. “Transgovernmental Relations and International Organizations". World Politics 27(1): 39-62.

Kinne, Brandon J. 2013. "Network Dynamics and the Evolution of International Cooperation". American Political Science Review 107(4): 766-785.

Maoz, Zeev. 2012. "Preferential Attachment, Homophily, and the Structure of International Networks, 1816-2003". Conflict Management and Peace Science 29(3): 341-369.

McCarty, Nolan. 2012. "The Political Economy of the Regulation and Self-Regulation of a Complex Industry". Paper presented at the Center for the Study of Democratic Politics (CSDP), Princeton, 20 September 2012.

McPherson, Miller, Lynn Smith-Lovin and James M Cook. 2001. "Birds of a Feather: Homophily in Social Networks". Annual Review of Sociology 27(1): 415-444.

Nganje, Fritz. 2015. "Decentralized Cooperation and the New Development Cooperation Agenda: What Role for the UN?" United Nations University Centre for Policy Research.

Niskanen, William A. 2007. Bureaucracy and Representative Government. New Brunswick Aldine Transaction Publishers. 
O'Connell, Philip J., and Jean-Marie Jungblut. 2008. "What Do We Know About Training at Work?" In Skill Formation: Interdisciplinary and Cross-National Perspectives, edited by Karl Ulrich Mayer and Heike Solga. New York: Cambridge University Press, 109-125.

Pavnick, Nina. 2000. "What Explains Skill Upgrading in Less Developed Countries?". NBER Working Paper $N^{\circ} 7846$.

Poole, Keith T. 2005. Spatial Models of Parliamentary Voting. New York: Cambridge University Press.

Raustiala, Kal. 2002. "The Architecture of International Cooperation: Transgovernmental Networks and the Future of International Law". Virginia Journal of International Law Association 43(1): 1-92.

Sarkar, Jayita. 2012. “Big State, Big Science, Big Projects: The Nuclear Energy Programme and State (Un)-Managerialism in India". Paper presented at the Rising Powers and the Future of Global Governance, University of Sussex, 16-17 May.

Schäfer, Armin, and Wolfgang Streeck. 2013. Politics in the Age of Austerity. Cambridge: Polity Press.

Schrank, Andrew. 2013. "From Disguised Protectionism to Rewarding Regulation: The Impact of Trade-Related Labor Standards in the Dominican Republic". Regulation \& Governance 7(3): 299-320.

Schwartzman, Simon. 1994. "Brazil Scientists and the State-Evolving Models and the 'Great Leap Forward'". In Scientists and the State: Domestic Structures and the International Context, edited by Etel Solingen. Ann Arbor: University of Michigan, 171-188.

Slaughter, Anne-Marie. 2004. A New World Order. Princeton: Princeton University Press.

Slaughter, Matthew Jon. 2002. "Skill Upgrading in Developing Countries: Has Inward Foreign Direct Investment Played a Role?". OECD Development Centre Working Papers 192.

Solingen, Etel. 1994. Scientists and the State: Domestic Structures and the International Context. Ann Arbor: University of Michigan Press.

Soulé-Kohndou, Folashadé. 2013. "The India-Brazil-South Africa Forum-a Decade On: Mismatched Partners or the Rise of the South?". GEG Working Papers 88.

Streeck, Wolfgang. 2012. "Skills and Politics: General and Specific". In The Political Economy of Collective Skill Formation, edited by Marius R. Busemeyer and Christine Trampusch. New York: Oxford University Press, 317-352.

Teodoro, Manuel P. 2011. Bureaucratic Ambition: Careers, Motives, and the Innovative Administrator. Baltimore: Johns Hopkins University Press.

Thelen, Kathleen. 2004. How Institutions Evolve: The Political Economy of Skills in Germany, Britain, the United States, and Japan. New York: Cambridge University Press.

Treier, Shawn, and Simon Jackman. 2008. "Democracy as a Latent Variable". American Journal of Political Science 52(1): 201-217.

Videras, Julio. 2013. "Social Networks and the Environment". Annual Review of Resource Economics 5(1): 211-226.

Vreeland, James Raymond. 2003. The IMF and Economic Development. New York: Cambridge University Press.

Isabella Alcañiz es la Profesora Distinguida Dr. Horace V. and Wilma E. Harrison de Política Ambiental 2014-2016 del Departamento de Gobierno y Política de la Universidad de Maryland, EEUU. Sus temas de investigación incluyen políticas de género, científicas, energéticas, burocráticas, y de medio ambiente en países en desarrollo con un énfasis en América Latina. Su trabajo ha sido publicado en diversas revistas especializadas, entre ellas World Politics, British Journal of Political Science (BJPS), Latin American Research Review (LARR), Latin American Perspectives (LAP), Environmental Science and Policy (ES\&P), Water Policy, Desarrollo Economico (Argentina), y la Revista Brasileira de Politica Internacional (Brasil). Su libro Environmental and Nuclear Networks in the Global South: How Skills Shape International Cooperation fue publicado por Cambridge University Press en Agosto 2016. La profesora Alcañiz tiene una Licenciatura en Relaciones Internacionales de la Universidad de Belgrano (Buenos Aires, Argentina) y un Doctorado en Ciencias Políticas de Northwestern University. Correo electrónico: ialcaniz@umd.edu 
